\title{
Rearing system and behavioural adaptation of laying hens to furnished cages
}

\author{
Sistema de cria e adaptação comportamental de poedeiras às gaiolas enriquecidas
}

\author{
Victor Fernando Büttow Roll ${ }^{I}$ Gustavo Adolfo Maria Levrino"I Ricardo Cepero Briz ${ }^{\text {II }}$
}

\begin{abstract}
The influences of floor and cage-rearing on behavioural adaptation to furnished cages were investigated in laying hens. Two groups of 180 Isa Brown commercial layer pullets were reared in cages (CR) or floor pens (FR) and transferred to furnished cages, where their behavioural adaptation was observed throughout the laying period (18-78 wks of age). At 17 weeks of age, hens were placed in one of the 36 furnished cages with 10 birds in each cage, each containing a nest box, perches, a dust bath, and abrasive strips. At 50 and 54 weeks of age, direct visual observation and video recording were used to assess hen's behaviour. From 21 weeks of age, the dust-bath activities of leg-banded hens in eight cages per treatment were recorded. The amount of time spent walking was higher (3.5\% vs. $1.8 \%$ ) and perching was lower (7.5\% vs. $13.4 \%)$ in $C R$ hens than in FR hens $(P<0.05)$. The use of dust baths and dust bathing behaviour increased throughout the laying period. The proportion of hens present at the sand bath area increased from $9.2 \%$ at 21 weeks to $21.4 \%$ at 72 weeks and the proportion of hens dust bathing increased from $4.7 \%$ to $21.0 \%(P<0.05)$. At 72 weeks of age, all dust-bath parameters were higher $(P<0.05)$ in $F R$ hens than in $C R$ hens.
\end{abstract}

Key words: behavior, dust-bath, welfare, nest, perches.

\section{RESUMO}

Neste trabalho, foi avaliada a influência dos sistemas de cria (em piso e em baterias) sobre a adaptação comportamental de poedeiras em gaiolas enriquecidas. Dois grupos de 180 frangas Isa brown foram criadas em baterias (CR) ou em piso (FR) e foram transferidas para gaiolas enriquecidas, onde a adaptação comportamental foi observada durante um ciclo completo de postura (18-78 semanas de idade). Com 17 semanas de idade, as frangas foram alojadas em 36 gaiolas enriquecidas, 10 aves por gaiolas, cada uma contendo um ninho, poleiros, banho de areia e lixas de unha. Nas semanas 50 e 54, foi utilizada observação direta e imagens de vídeo para a análise do comportamento. A partir de 21 semanas de idade, a atividade de banho de areia em galinhas marcadas com anilhas foi registrada em 8 gaiolas por tratamento. As aves CR gastaram mais tempo caminhando (3,5\% vs. $1,8 \%$,) e menos tempo empoleiradas $(7,5 \%$ vs. $13,4 \%)$, se comparadas com as FR $(P<0,05)$. O número de aves presentes nos banhos de areia aumentou de $9,2 \%$ às 21 semanas para $21,4 \%$ às 72 semanas de idade, enquanto que a proporção de galinhas realizando o banho aumentou de 4,7\% para $21,0 \%(P<0,05)$. Com 72 semanas de idade, todos os parâmetros de uso de banho de areia foram maiores $(P<0,05)$ nas FR em comparação com a CR.

Palavras-chave: bem-estar, criação, comportamento, gaiolas enriquecidas, banho de areia.

\section{INTRODUCTION}

The advantages of rearing in cages are the manure cleanout is easier to manage, a better control of any parasites and it allows higher bird density per cubic capacity of building, whereas the disadvantages are the need for a specialized building structure and equipment causing higher initial investment costs, so producers can reduce their production cost when pullets are reared using the floor system.

In general, comfort behaviours, such as preening, stretching, feather ruffling and wing movements are more prevalent among birds in a floor-

IDepartamento de Zootecnia, Universidade Federal de Pelotas (UFPel), Faculdade de Agronomia Eliseu Maciel,Campus Universitário s/n, CP 354, 96010-900, Pelotas, RS, Brasil. E-mail:roll98@ufpel.edu.br. Autor para correspondência.

IIUniversity of Zaragoza, Department of Animal Production \& Food Science, Faculty of Veterinary Medicine. Miguel Servet, 177, (50013) Zaragoza, Spain. 
rearing system. It is, however, unclear whether those behaviours are carried over into the laying cycle or how furnished laying cages affect the expression of those behaviours.

To address some of those problems, alternative rearing systems have been developed. Cage modifications, such as increasing the cage area, placing divisions within the cage, and including perches and a nest, improve the welfare of birds (APPLEBY, 1998). Providing birds with access to litter, such as sand in a dust bath, has behavioural and physical effects. Pecking, scratching, and dust bathing can improve the condition of feet, claws and beaks (FICKENWIRTH et al., 1985). NICOL et al. (2001) demonstrated that exposure to wood shavings at an early age influences the dust-bathing behaviour of laying hens. On the other hand, OKPOKHO \& CRAIG (1987) found that rearing environment did not influence fear related behaviour in laying hens.

In Spain, about $6 \%$ of all pullets are reared using the floor system. The transition to laying cages is a sudden and pronounced change in the environment of those birds (ANDERSON et al., 1989; ANDERSON \& ADAMS, 1994). This fact could be more important if the commercial cages are furnished. It is important to know whether and how different rearing systems affect the behaviour and the welfare of hens.

Considering the suggestion of ANDERSON et al., (1989) that floor reared pullets are subjected to a drastic change in environment when housed in cages we have thought that adaptation behavioural problems can cause great economic losses under commercial conditions and impair animal welfare.

If there are differences between rearing system that can affect negatively or positively on production period of hens they they must be found. We have believed that our results could help to decide wich rearing system is more appropriate and brings less adverse consequence to the welfare of the birds as well as the economy of a farm. In this paper we assess the effect of rearing system (cage or floor) on behaviour of laying hens housed in furnished cages.

\section{MATERIALS AND METHODS}

Three hundred and sixty beak-trimmed pullets of a commercial strain (Isa Brown) were purchased from a local breeder. On the farm of origin, half of the birds were reared in standard rearing cages and the other half were reared in floor pens with litter.

The management of both treatments was otherwise similar and all birds were managed according to standard commercial practices. The daily photoperiod was decreased from $24 \mathrm{~h}$ at 1-day-old to 10h light/day at 49 days of age, and this photoperiod was maintained to the end of the rearing period. In order to have an effective light programme and to control sexual maturity an intensity of up 40 lux was used.

The chicks were given standard pullet feed in three phases, which consisted of 21\% CP, $2.823 \mathrm{kcal}$ $\mathrm{ME} \mathrm{kg}^{-1}$ starter diet from 0-6 weeks, $18 \% \mathrm{CP}, 2.864 \mathrm{kcal}$ $\mathrm{ME} \mathrm{kg}^{-1}$ grower diet from 7-12 weeks, and 16\% CP, $2.724 \mathrm{kcal} \mathrm{ME} \mathrm{kg}^{-1}$ developer diet from 13-17 weeks.

At 17 weeks of age, the birds were transferred to the Poultry Experimental Unit of the University of Saragossa and randomly allocated to one of 36 furnished cages, each with 10 birds per cage. There were 2 main treatments, arranged in 2 blocks of 18 cages. The furnished cages have a nest and litter at the rear (Figure 1). The cages were $120 \mathrm{~cm}$ wide, $63 \mathrm{~cm}$ deep, and $40 \mathrm{~cm}$ high at the front and $45 \mathrm{~cm}$ high at the back, with a floor slope of $12^{\circ}$. The average area per bird was $600 \mathrm{~cm}^{2}$ in the main part of the cage and $150 \mathrm{~cm}^{2}$ in the nest area (total floor space per bird was $750 \mathrm{~cm}^{2}$ ). Feeder area was $12 \mathrm{~cm}$ per bird and space in the dust bath was $120 \mathrm{~cm}^{2}$ per bird.

From 18 to 78 weeks of age, hens had ad libitum access to water and normal layer crumbled rations with $2.892 \mathrm{kcal}^{\mathrm{kg}}{ }^{-1}$ metabolizable energy and $17 \%$ crude protein. The light:dark regime was 16:8. Air temperature was maintained between 20 and $24^{\circ} \mathrm{C}$. Hens were permitted access to a dust bath for $2 \mathrm{~h}$ per day (13:00-15:00h, after egg collection). To prevent hens from staying in the litter box area, expulsion system was used. We chose that period to prevent hens from laying in the dust bath, and to have the hens adjust to the working hours of farm employees. Faeces were removed with conveyor belts and dust baths were filled with sawdust (previously passed through a sieve), automatically, using conveyor belts on alternate days. From 19 to 78 weeks of age, production data (including the number of damaged or dirty eggs) were collected daily.

To establish whether FR and CR hens differed in their behaviour, we observed the birds at 50 and 54 weeks of age on three consecutive days, and recorded their behaviour using scan sampling (LEHNER, 2003). To minimize the effects of the observer on hen's behaviour, the observer was always the same person, who always wore the same clothes, and was positioned approximately $1 \mathrm{~m}$ from the cages. Scans were taken every minute in each cage (all cages were observed) for a period of $3 \mathrm{~h}$ beginning at 16:00h. The observer 


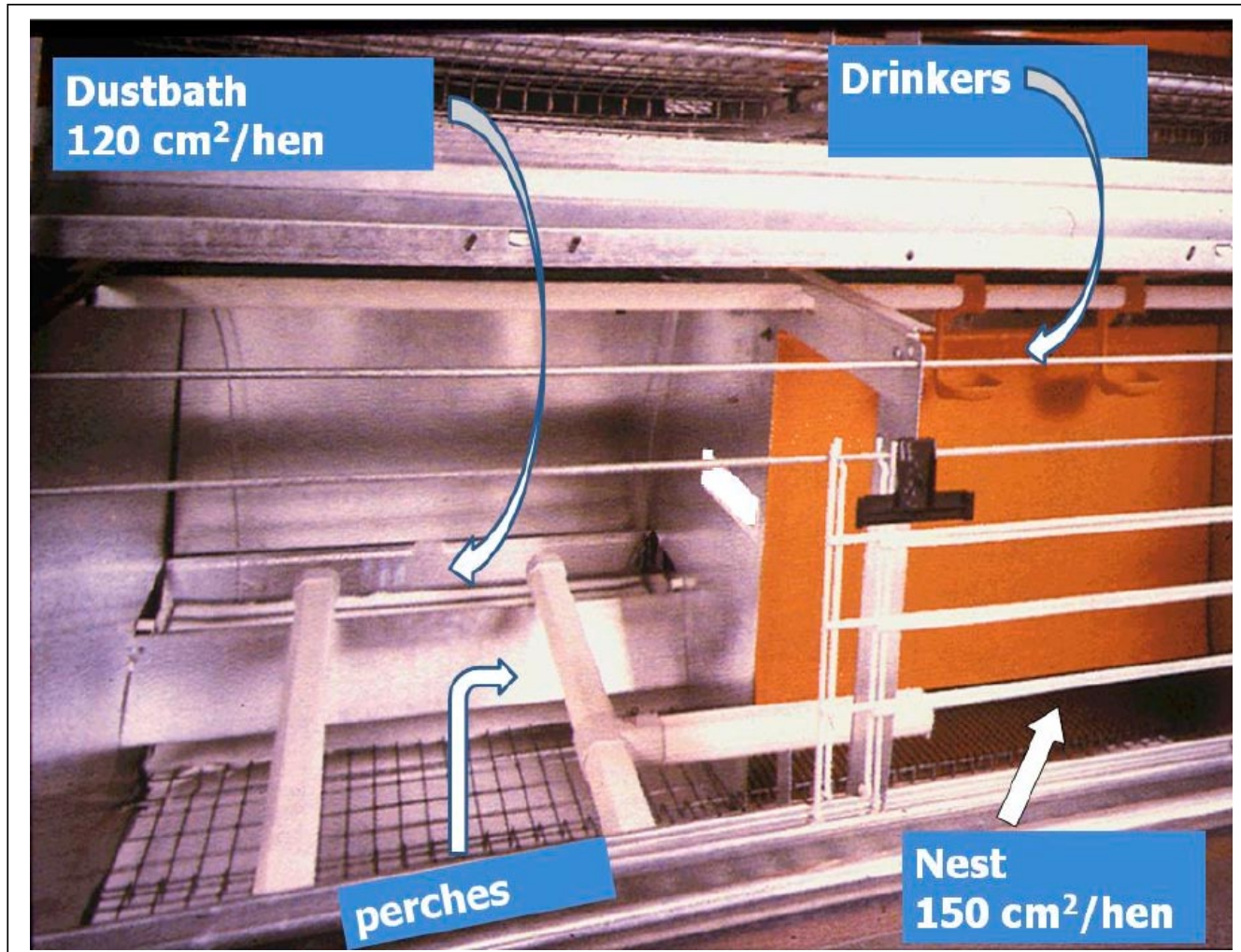

Figure 1 - Schematic representation of the furnished cages used in the experiment.

recorded the number of hens feeding (insertion of the head in the trough), drinking (drinking water from the water dispenser), perching (standing, resting or stepping on the perch), walking (taking at least one step in a given direction), alert (bird appearing to vigilant, head moving quickly from side to side), standing (upright and alert in one place), preening (running the beak through the feathers), foraging (nonaggressive pecking at anything other than feed trough, but primarily litter pecking at the dust bath); stretching (unilateral wing-leg stretching), flapping (raising and lowering wings), and feather pecking (from gentle pecking to feather removal). Descriptions of behaviours are adapted from, WEBSTER (2000), and ELSTON et al. (2000). This recording method allowed calculation of the proportion of time which hens spent in different activities. The percentage of hens engaged in each behaviour was calculated from the total number of hens observed during all scan samples in each cage.

To obtain a detailed description of dustbathing activity, we monitored the behaviour of the birds when the dust baths were open ( $2 \mathrm{~h}$ between 13:0015:00h), using the procedures described by SMITH et al. (1993). We did one observational session in eight cages per treatment at 21, 26, 40 and 72 weeks of age, and recorded the number of hens in the bath, dust bathing performance, and activity level. An observational session consisted of two day observations. Focal animal samples were taken every minute to assess the dust bath activity. All hens performing activities in the bath, each pen, was observed 15 times/day (between 13:00-15:00h) by two observers in a randomised order. The level of dust bathing activity was measured by scoring the intensity of rapid body shakes, based on a scale from 1 (smooth), 2 (moderate) to 3 (strong). Active dust bathing includes siderubbing, head-rubbing, vertical wing shaking and sidelying with scratching (DUNCAN et al., 1998). Dust bathing is considered to begin after the first vertical wing shake.

To verify that all of the hens were able to dust bathe, when the birds were 50-51, 63-64 and 73-74 weeks old, we documented individual use of the dust bath during work days (Monday-Friday). For those observations, we used eight cages (four per treatment) and the focal birds had leg bands. When a hen was observed in the bath, it was caught, marked and released on the bath as quickly as possible.

To test for differences in the frequency of different types of behaviour we used the Wilcoxon rank 
sum procedure (Mann-Whitney U-test). Floor and cage-rearing were treated as the experimental unit and, for all traits, individual cages were used as replicates. The level for statistical significance was set at $(\mathrm{P}=0.05)$ and statistical tests were performed using SPSS 11.0 for Windows, 2004.

\section{RESULTS AND DISCUSSION}

Between 16:00-19:00h hen time budgets shows that hens spent most of their time feeding and, in this respect there was no significant difference between treatments (44.9\% in CR hens; $41.4 \%$ in FR hens). The amount of time spent drinking was similar in the two treatment groups (12.5\% in CR hens; $11.2 \%$ in FR hens). Treatment groups differed significantly ( $\mathrm{U}=1751, \mathrm{P}<0.001$; Wilcoxon $\mathrm{W}=4379 \mathrm{P}<0,001)$ in the amount of time spent perching (7.5\% in CR hens, $13.4 \%$ in FR hens). The amount of time hens spent foraging varied between 6.5 and $7.0 \%$ and the differences were not significant. The amount of time spent walking differed significantly $(\mathrm{U}=2124 \mathrm{P}<0.01 \mathrm{~W}=4752 \mathrm{P}<0.01)$ between rearing systems. The amount of time spent walking was higher (3.5\%) in CR hens than in FR hens (1.8\%). Typically, the amount of time spent in comfort behaviours, such as preening, stretching, wing movements, was low and unaffected by rearing treatments.

Prior to this study, we suspected that birds reared in floor cages would be, as adults, more likely to continue exhibiting comfort behaviours, such as preening, stretching, feather ruffling and wing movements. In general, rearing system did not seem to affect behaviour to any significant extent; however, some differences in the behaviour of FR and CR hens were evident; e.g., perching, dust bathing and movement, especially at the beginning of laying period. It is unclear, however, why FR hens perched more often since they had no previously experience with perches. That behaviour might be partially explained by an interaction between the ontogeny of foraging and other "floor-related" behaviours in FR birds during the rearing period, which led to the development of more frequent perching behaviour in the cage (LAMBE et al., 1997). The benefits of a perch to the welfare of caged hens are not clear (GLATZ \& BARNETT, 1996; DUNCAN et al., 1992). Hens housed in litter and free range sit less and stand less (APPLEBY et al., 1992); therefore, the greater use of perches by FR hens probably does not indicate better animal welfare. That finding is consistent with the evidence that CR hens walking more than FR hens, which probably is derived from early experience in cages. This might be associated with a greater exploratory behaviour and a better ability to move within a small space containing obstacles (e.g., perches).

Data on the use of the dust bath area are presented in table 1 . The use of dust baths and dust

Table 1 - The number of hens present in the dust bath area, number of hens performing dust bath behaviour, and the intensity of dust bathing in Floor-reared and Cage-reared Isa Brown laying hens housed in furnished cages.

\begin{tabular}{|c|c|c|c|c|}
\hline \multirow{2}{*}{ Parameter } & \multirow[b]{2}{*}{ Age } & \multicolumn{3}{|c|}{ 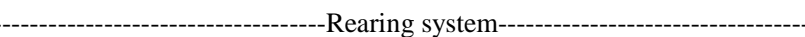 } \\
\hline & & Cage & Floor & Total \\
\hline \multirow{4}{*}{$\begin{array}{l}\text { Number of hens present in the } \\
\text { dust bath }\end{array}$} & 21 & $0.54 \pm 0.04^{b}$ & $1.27 \pm 0.04^{\mathrm{a}}$ & $0.92 \pm 0.03^{\mathrm{C}}$ \\
\hline & 26 & $1.57 \pm 0.05^{\mathrm{a}}$ & $1.47 \pm 0.06^{\mathrm{a}}$ & $1.53 \pm 0.04^{\mathrm{B}}$ \\
\hline & 40 & $2.01 \pm 0.05^{b}$ & $2.15 \pm 0.06^{\mathrm{a}}$ & $2.07 \pm 0.04^{\mathrm{A}}$ \\
\hline & 72 & $2.06 \pm 0.07^{b}$ & $2.23 \pm 0.08^{a}$ & $2.14 \pm 0.05^{\mathrm{A}}$ \\
\hline \multirow{4}{*}{ Performing dust-bathing } & 21 & $0.35 \pm 0.07^{b}$ & $0.58 \pm 0.07^{\mathrm{a}}$ & $0.47 \pm 0.05^{\mathrm{C}}$ \\
\hline & 26 & $0.92 \pm 0.08^{b}$ & $1.15 \pm 0.09^{\mathrm{a}}$ & $1.02 \pm 0.06^{\mathrm{B}}$ \\
\hline & 40 & $1.84 \pm 0.08^{\mathrm{a}}$ & $1.83 \pm 0.09^{\mathrm{a}}$ & $1.84 \pm 0.06^{\mathrm{A}}$ \\
\hline & 72 & $2.00 \pm 0.12^{b}$ & $2.20 \pm 0.12^{\mathrm{a}}$ & $2.10 \pm 0.08^{\mathrm{A}}$ \\
\hline \multirow{4}{*}{ Dust-bathing activity level $^{1}$} & 21 & $0.38 \pm 0.05^{b}$ & $0.54 \pm 0.04^{\mathrm{a}}$ & $0.47 \pm 0.03^{\mathrm{D}}$ \\
\hline & 26 & $1.21 \pm 0.06^{\mathrm{a}}$ & $1.0 \pm 0.06^{\mathrm{a}}$ & $1.11 \pm 0.04^{\mathrm{C}}$ \\
\hline & 40 & $2.09 \pm 0.06^{\mathrm{a}}$ & $2.37 \pm 0.06^{a}$ & $2.21 \pm 0.04^{\mathrm{A}}$ \\
\hline & 72 & $1.57 \pm 0.08^{b}$ & $1.79 \pm 0.08^{\mathrm{a}}$ & $1.68 \pm 0.06^{\mathrm{B}}$ \\
\hline
\end{tabular}

Means within rows (rearing effect) with no common superscripts differ significantly (at least $\mathrm{P}<0.05$ ).

Means within columns (age effect) with no common capital superscripts differ significantly (at least $\mathrm{P}<0.05$ ).

${ }^{1}$ Assessed by score from 1 (very low intensity) to 3 (very high intensity). 
bathing behaviour were significantly affected by rearing system $(\mathrm{P}<0.05)$, and increased throughout the laying period. That result suggests that the hens learned how to use the dust bath over time. For dust bathing, there was a significant interaction between rearing system and age. The proportion of hens present at the sand bath area increased from $9.2 \%$ at 21 weeks to $21.4 \%$ at 72 weeks. In that period, the proportion of hens dust bathing increased from $4.7 \%$ to $21 \%$. Until 40 weeks of age older hens performed more intensive dust bathing. At the end of the laying period the intensity of dust bathing decreased slightly. At the beginning of the production cycle, FR hens exhibited significantly more dust bathing activity than did CR hens. At 21 weeks of age there were more FR hens in the dust bath, they dust bathed more often, and were more active than $\mathrm{CR}$ hens $(\mathrm{P}<0.05)$. At 26 weeks of age the number the hens in dust baths did not differ significantly, but dust-bathing and activity levels differed significantly $(\mathrm{P}<0.05)$ between treatment groups. At 40 weeks of age there were no differences between treatment groups, except the number of hens in litter was higher in FR hens. At 72 weeks of age, all dust-bath parameters were higher $(\mathrm{P}<0.05)$ in $\mathrm{FR}$ hens than in CR hens. Collectively, our results suggest that access to litter during rearing increased the use of dust baths.

Our results do not support the view of GUNNARSSON et al. (1999), who suggested that rearing effects are more likely to be evident during the first four months of egg production, because we found differences in the frequency of dirty eggs, eggshell quality, plumage condition, and dust-bathing performance at the end of the production cycle. ANDERSON \& ADAMS (1994) also found differences for tonic immobility at the end of lay.

Hens can adjust their behaviour in a few days after being transferred to conventional cages (TANAKA \& HURNIK, 1992; ANDERSON et al., 1989); however, our data suggest that early experience with litter in floor-rearing systems can affect dust-bathing behaviour throughout the laying period when hens are housed in furnished cages. NICOL et al. (2001) also found that early substrate imprinting can affect the development of other behaviours in the adult laying hen, such as feather pecking, dust-bathing, and foraging. HUBER-EICHER \& SEBÖ (2001) reported that access to litter at an early age reduces feather pecking and increases foraging behaviour in aviaries maintained under commercial conditions.
Dust-bathing is one of the most difficult behaviour patterns to assess because it is influenced by internal and external factors (PETHERICK et al., 1995). According to VEESTERGAARD et al. (1997), hens are highly motivated to dust bathe, but FAURE \& LAGADIC (1994) suggested that dust bathing is not a behavioural imperative for hens. In our study, at 21 weeks of age, more FR hens were in the dust bath, they dust bathed more often, and had higher activity levels than did CR hens. That result might be because the floor -reared hens had previous experience with litter (NICOL et al., 2001). Additionally, dust bathing increased throughout the laying period, as was found in another study (VESTERGAARD et al., 1997). In general, FR hens performed better in the dust bath than did CR hens, but this difference decreased as hens aged. One possible explanation for that pattern is that the learning process of $\mathrm{CR}$ hens was effective after a few weeks in the cage, and dust bathing provides a strong positive reinforcement for the hens.

All of the hens in a cage could not access the dust bath area simultaneously; therefore, we asked whether all of the hens use a sand bath over a period of $10 \mathrm{~d}$. At 50, 63 and 73 weeks of age, we recorded which hens used a dust bath in two hours of observation per day over five and ten consecutive days. At 73 weeks of age, the proportion of FR hens in the dust bath (93\%) was significantly $(\mathrm{P}<0.05)$ higher than the proportion of CR hens (75\%). For both treatments, the maximum proportion if hens that used a dust bath was approximately $93 \%$ on the $10^{\text {th }}$ day of observation. In the 5 -day period, about $25 \%$ of the hens did not use the dust bath, nearly $50 \%$ of the hens used it once, and $75 \%$ used it twice. Few hens (approximately 9\%) were present in a dust bath on more than three days, and only one hen was observed in the dust bath on all five days of observation. More than $20 \%$ of the hens never visited the dust bath area during the observation period. The size of the dust bath area and the availability of appropriate substrate might lead to decreased motivation of the hens housed in a commercial cage and hens are more stongly motivated by other behaviour patterns, such as feeding and drinking. External factors, such as new litter material in the box also play an important role in the expression of dust-bathing behaviour (PETHERICK et al., 1995). After entering a dust bath, there were no differences between FR and CR hens 
in the intensity (score) of dustbathing behaviour, which declined over time in both treatment groups.

According to LAGADIC \& FAURE (1987), litter is essential for the performance of dust bathing, and to be deprived of litter is stressful or aversive to birds. We observed more dust bathing on the days that fresh sawdust was placed in the nest $(3.43 \pm 0,1 \mathrm{vs}$ $2.52 \pm 0.13$ hens/day), which implies that quantity and quality of litter is important as an external stimuli for the performance of dust bathing activity. In our study, the intermittent addition of fresh sawdust increased the cost of furnished cages by about 0.4 Euro per hen/wk.

Our results and those of GUNNARSSON et al. (2000) show that dust bathing begins immediately after a dust bath is opened. The number of FR hens in a dust bath $15 \mathrm{~min}$ after a bath was opened was significantly $(\mathrm{P}<0.05)$ higher than other times. In our study, the number of hens present in the dust bath area and the number of hens dust bathing declined after the dust bath was opened, which suggests that habituation occurs in the hens (Table 2). The number of hens dust bathing decreased within one hour of the start of observations, which might indicate that this behaviour is a preference, but not a necessity for hens, as suggested by FAURE \& LAGADIC (1994). WIDOWSKY \& DUNCAN (2000) showed that hens are unwilling to work harder to obtain access to a dust bathing when they are deprived of the opportunity to perform this behaviour.

\section{CONCLUSIONS}

Behavioural adaptation by hens to furnished cages during the laying period was successful in hens reared on floors or cages, and we found no evidence of poor welfare as a consequence of the rearing conditions used in this study. There was evidence of increased use of dust bath by floor-reared birds. The higher level of use of dust bath in the floor-reared hens in this experiment may have been a result of the previous exposure to litter. On the other hand, our results suggest that the hens learned how to use the dust bath over time. Furthermore, we provided the evidence that two $\mathrm{h} / \mathrm{d}$ of dust bath opening are insufficient to give opportunity to all of the hens use a sand bath over a period of 10 days.

\section{ACKNOWLEDGEMENTS}

This research was supported by the Ministry of Science and Technology of Spain (Projects AGF97-0932 and PETRI PTR 1995 0449-OP) and co-supported by Zucami Poultry Equipment Company, The Spanish Association of Egg Producers (INPROVO) and the Ministry of Agriculture \& Fisheries of Spain. The authors would like to thank Conselho Nacional de Desenvolvimento Científico e Tecnológico (CNPq) from Brazil for the financial support of the Ph. D. student Victor Fernando Büttow Roll.

Table 2 - Average number of hens present in the dust bath, average number of birds dust bathing and dust bath activity intensity at 15, 30, 45 and 60 minutes after opening the dust bath area.

\begin{tabular}{lccc}
\hline & Time & Cage & Floor \\
\hline \multirow{3}{*}{ Hens present at dust bath } & $15^{\prime}$ & $1.56 \pm 0.06^{\mathrm{bA}}$ & $1.86 \pm 0.07^{\mathrm{aA}}$ \\
& $30^{\prime}$ & $1.39 \pm 0.07^{\mathrm{bAB}}$ & $1.62 \pm 0.07^{\mathrm{aB}}$ \\
& $45^{\prime}$ & $1.25 \pm 0.07^{\mathrm{bB}}$ & $1.46 \pm 0.07^{\mathrm{aB}}$ \\
& $60^{\prime}$ & $1.29 \pm 0.06^{6 \mathrm{BB}}$ & $1.62 \pm 0.07^{\mathrm{aB}}$ \\
& $15^{\prime}$ & & $1.49 \pm 0.11^{\mathrm{aA}}$ \\
Hens performing dust-bathing & $30^{\prime}$ & $1.26 \pm 0.09^{\mathrm{bA}}$ & $1.22 \pm 0.1^{\mathrm{aA}}$ \\
& $45^{\prime}$ & $1.08 \pm 0.1^{\mathrm{aAB}}$ & $1.13 \pm 0.11^{\mathrm{aA}}$ \\
& $60^{\prime}$ & $0.95 \pm 0.1^{\mathrm{aB}}$ & $1.16 \pm 0.1^{\mathrm{aA}}$ \\
& $15^{\prime}$ & $1.06 \pm 0.9^{\mathrm{aBB}}$ & $1.52 \pm 0.09^{\mathrm{aA}}$ \\
Dust-bathing intensity (1-3) & $30^{\prime}$ & $1.35 \pm 0.07^{\mathrm{aA}}$ & $1.15 \pm 0.08^{\mathrm{aC}}$ \\
& $45^{\prime}$ & $1.10 \pm 0.08^{\mathrm{aB}}$ & $0.93 \pm 0.09^{\mathrm{aC}}$ \\
\hline
\end{tabular}

Means within rows (rearing effect) with no common superscripts differ significantly $(\mathrm{p}=0,05)$.

Means within columns (time effect) with no common capital superscripts differ significantly (at least $\mathrm{p}=0,05$ ).

Ciência Rural, v.38, n.7, out, 2008. 


\section{REFERENCES}

ANDERSON, K.E. et al. Behavioral adaptation of floorreared white Leghorn pullets to different cage densities and cage shapes during de initial settling-in period. Poultry Science, Savoy, v.68, n.1, p.70-78, 1989.

ANDERSON, K.E.; ADAMS, A.W. Effect of floor versus cage rearing and feeder space on growth, long bone development, and duration of tonic immobility in Single Comb White Leghorn pullets. Poultry Science, Savoy, v.73, n.7, p.958-964, 1994.

APPLEBY, M.C. Modification of laying hen cages to improve behaviour. Poultry Science, Savoy, v.77, n.12, p.18281832, 1998.

APPLEBY, M.C. et al. Poultry production systems: behaviour, management and welfare. Wallingford: CABI International, 1992. 240p.

DUNCAN, E.T. et al. Effects of perches in laying cages on welfare and production of hens. British Poultry Science, London, v.33, n.1, p.25-35, 1992.

DUNCAN, J.H. et al. External factors and causation of dustbathing in domestic hens. Behavioural Processes, Amsterdam, v.43, n.2, p.219-228, 1998.

ELSTON, J.J. et al. Laying hen behaviour. Effect of cage type and startle stimuli. Poultry Science, Savoy, v.79, n.4, p.471-476, 2000.

FAURE, J.M.; LAGADIC, H. Elasticity of demand for food and sand in laying hens subjected to variable wind speed. Applied Animal Behaviour Science, Amsterdam, v.42, n.2, p.49-59, 1994.

FICKENWIRTH, A.D.W. et al. Sand shortens the claws and beak hens prevents injuries. In: WEGNER, R.M. (Ed.) Proceedings of Second European Symposium on Poultry Welfare. Germany: World's Poultry Science Association, Ce11e, 1985. p.288-290.

GLATZ, P.C.; BARNETT, J.L. Effect of perches and solid slides on production, plumage condition of laying hens housed in conventional cages in a natural ventilated shed. Australian Journal of Experimental Agriculture, Melbourne, v.36, n.3, p.269-275, 1996.

GUNNARSSON, S. et al. Effect of rearing factors on the prevalence of floor eggs, cloacal cannibalism and feather pecking in commercial flocks of loose housed laying hens British Poultry Science, London, v.40, n.1, p.12-18, 1999.
GUNNARSSON, S. et al. The demand for straw and feathers as litter substrates by laying hens. Applied Animal Behaviour Science, Amsterdam, v.65, n.4, p.321-330, 2000.

HUBER-EICHER, B.; SEBÖ, F. Reducing feather pecking when raising laying hen chicks in aviary systems. Applied Animal Behaviour Science, Amsterdam, v.73, n.l-2, p.5968, 2001.

LAGADIC, N.R.; FAURE, J.M. Performance of domestic hens for cage size and floor types as measured by operant conditioning. Applied Animal Behaviour Science, Amsterdam, v.19, n.12, p.147-155, 1987.

LAMBE, N.R. et al. Behaviour of laying hens negotiating perches at different heights. Animal Welfare, Potters Bar, v.6, n.1, p.29-41, 1997.

LEHNER, P. Handbook of ethological methods 2.ed. Cambridge: University of Cambridge, 2003.672p.

NICOL, C.J. et al. Influence of prior exposure to wood shaving on feather pecking, dusthbathing and foraging in adult laying hens. Applied Animal Behaviour Science, Amsterdam, v.73, n.2, p.141-155, 2001.

OKPOKHO, N.A.; CRAIG, J.V. Fear related behaviour of hens in cages: effects of rearing environment, age and habituation. Poultry Science, Savoy, v.66, n.2, p.376-377, 1987.

PETHERICK, J.C. et al. The role of perception in the causation of dusthbathing behaviour in domestic fowl. Animal Behaviour, London, v.49, n.6. p.1521-1530, 1995.

SMITH, S.F. et al. Nesting and dust bathing by hens in cages: Matching and mis-matching between behaviour and environment. British Poultry Science, London, v.34, n.l, p.21-33, 1993.

TANAKA, T.; HURNIK, J.F. Comparison of behaviour and performance of laying hens housed in battery cages and aviary. Poultry Science, Savoy, v.71, n.2, p.235-243, 1992.

VEESTERGAARD, K.S. et al. The stress of not being able to perform dustbathing in laying hens. Physiology \& Behavior, Elmsford, v.2, n.2, p.413-419, 1997.

WEBSTER, A.B. Behaviour of white Leghorn hens after withdrawal of feed. Poultry Science, Savoy, v.79, n.2, p.192-200, 2000.

WIDOWSKY, T.M.; DUNCAN, J.H. Working for dusthbath: are hens increasing pleasure rather than reducing suffering. Applied Animal Behaviour Science, Amsterdam, v.68, n.1, p.39-53, 2000. 